Fall 1997

\title{
Ethnic Tourism and the Renegotiation of Tradition in Tana Toraja (Sulawesi, Indonesia)
}

Kathleen M. Adams

Loyola University Chicago, kadams@luc.edu

Follow this and additional works at: https://ecommons.luc.edu/anthropology_facpubs

Part of the Anthropology Commons

\section{Recommended Citation}

Adams, K. (1997). "Ethnic Tourism and the Renegotiation of Tradition in Tana Toraja (Sulawesi, Indonesia)." Ethnology, 36(4), p. 309-320.

This Article is brought to you for free and open access by the Faculty Publications and Other Works by Department at Loyola eCommons. It has been accepted for inclusion in Anthropology: Faculty Publications and Other Works by an authorized administrator of Loyola eCommons. For more information, please contact ecommons@luc.edu. cc) (i) $\Theta$

This work is licensed under a Creative Commons Attribution-Noncommercial-No Derivative Works 3.0 License. (c) University of Pittsburgh, Department of Anthropology, 1997. 


\title{
ETHNIC TOURISM AND THE RENEGOTIATION OF TRADITION IN TANA TORAJA (SULAWESI, INDONESIA) ${ }^{1}$
}

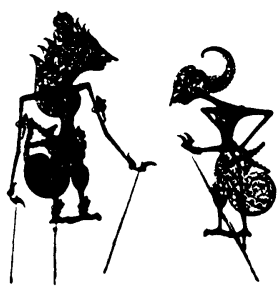

Kathleen M. Adams

Loyola University of Chicago

\begin{abstract}
This article examines some of the political and symbolic issues inherent in the touristic renegotiation of Torajan ritual and history, chronicling the strategies whereby Torajans attempt to refashion outsider imagery to enhance their own personal standing and position in the Indonesian ethnic hierarchy. The author suggests that the Toraja case challenges the popular assumption that tourism promotion brings a complete loss of agency to indigenous peoples: Torajans not only engage in ingenious political strategies to enhance their group's image, but vigorously contest perceived threats to their identity and power. The author argues that such processes of self-conscious cultural reformulation do not necessarily imply a collapse in meaning or emotive power; rather, the Toraja case lends support to recent calls to rethink the discourse of "authenticity" and "staged authenticity." (Toraja, tourism, Indonesia, ethnic imagery, invention of tradition)
\end{abstract}

In January of 1987, tourists descending from jets at the Ujung Pandang airport in South Sulawesi, Indonesia, were greeted with a mimeographed announcement of an elaborate, pageantry-filled funeral ceremony to be held in the Toraja highlands for the late $\mathrm{Ne}$ ' Ke'te'. ${ }^{2}$ Using a smattering of anthropological terminology, the pamphlet outlined the cultural functions of Torajan funeral rituals, made reference to a Torajan origin myth, and presented a schedule of events for the ten-day funeral ritual. Hoteliers and travel agents boasted that this was the first Torajan funeral ceremony that would adhere to a definite time schedule; this time no tourists would be disappointed with the last-minute postponements so typical of Torajan rituals. Television newscasters declared that this promised to be a "truly unique Torajan event: the largest, most elaborate, and impressive funeral in several decades." As exceptional as this barrage of publicity was, the funeral (which was for my former Torajan mentor) proved to be momentous, but for very different reasons than those heralded in the media.

Since the early 1970s, tourists have been visiting the Toraja highlands in ever-increasing numbers. In 1994 alone, approximately 53,700 foreign tourists and 205,000 domestic tourists $^{3}$ journeyed to the Toraja homeland, lured by guidebook accounts of Torajans' pageantry-filled funeral rituals, haunting burial cliffs, elaborate architecture, and breathtaking scenery. Touristic celebrity has precipitated a number of new issues for the Toraja, certain aspects of which have been discussed elsewhere (Adams 1984, 1993a, 1993b, 1995; Crystal 1977, 1994; Volkman 1987, 1990; Yamashita 1994). This article concerns the ways in which Torajan history and custom are being reshaped as a result of tourism development. Over the past two decades, anthropologists and historians have become increasingly concerned with processes of cultural construction and invention (cf. Wagner 1981 [1975]; Keesing and Tonkinson 
1982; Hobsbawm and Ranger 1983; Linnekin 1983, 1992; Handler and Linnekin 1984; Clifford 1988; Jackson 1989; Hanson 1989; Keesing 1989; White and Lindstrom 1993). As many have stressed, in order to advance our understanding of the construction of tradition, our questions must go beyond examinations of which aspects of culture are authentic and which are invented (White 1991:3). Closer attention must be paid to the processes whereby traditions are invented and the conditions under which custom is renegotiated. This article explores some of the microprocesses involved in the contemporary renegotiation of Toraja history and ritual practice. Whereas the majority of studies of the "invention of tradition" concern the artificial creation of ritual traditions by colonial governments or indigenous elites, the focus here is on a different sort of context in which tradition is negotiated: that of ethnic tourism. As the Toraja case suggests, encounters with foreign tourists (and a national government interested in further stimulating tourism revenues) are prompting new challenges to local forms of meaning, power, and identity. In short, ethnic tourism creates a fertile context for the reinterpretation of history and custom. Specifically, this essay explores the contemporary Torajan engagement with touristic imagery and chronicles the strategies whereby Torajans attempt to refashion this outsider imagery in order to enhance their position in the Indonesian hierarchy of ethnic groups (as well as their own local standing).

Various writers have suggested that ethnic tourism engenders "staged authenticity" and "museumification" (cf. MacCannell 1973, 1976, 1992; Cohen 1988, 1989). That is, as a tourist-hosting society undergoes economic and cultural changes through its intensifying contact with outsiders, efforts are made to stage the traditional cultural rituals and activities that are becoming increasingly rare and increasingly divorced from their original cultural significance. While the explosion of traditional Torajan architectural embellishments and family-run museums in tandem with tourism development certainly resonates with this notion of staged authenticity, the cases discussed in the following pages underscore the fact that self-conscious staging of rituals does not entail a loss of meaning for local people. Despite the fact that largescale Torajan funerals are increasingly sculpted to address the needs and expectations of visiting tourist dignitaries, these ritual events continue to carry tremendous cultural significance for Torajan participants. As Crick (1989:336) so cogently asks in reflecting on the problematic concept of authenticity, "What in a culture is not staged? What does cultural authenticity consist of?"

Data here are drawn from fieldwork in the Toraja highlands in 1984-1985 and subsequent visits in $1987,1991,1992$, and 1995 . Central to the analysis are two events: the highly publicized funeral ritual referred to at the beginning of this article and a Local Guide Training Workshop in the Toraja highlands that sparked a reverberating emotional debate among Torajans. In different ways, both cases illustrate the issues central to Torajan efforts at ethnic imagery enhancement and address ongoing anthropological discussions about cultural authenticity and the invention of tradition. 


\section{THE SA'DAN TORAJA: ETHNOGRAPHIC BACKGROUND}

The Sa'dan Toraja homeland is in Tana Toraja Regency, a mountainous interior region of South Sulawesi, Indonesia. Traditionally, most Torajans have been wet rice cultivators, although in recent years many farmers have also planted cash crops such as coffee and cloves. Today Torajans can also be found in a variety of occupations, working as teachers, bureaucrats, mining workers, servants, and tour guides in cities throughout Indonesia. In a nation of over 185 million people, the Sa'dan Toraja constitute a small minority, numbering approximately 350,000 .

The Toraja people are marginalized by geography, religion, and a diffuse power structure. Their closest neighbors are the Islamicized Buginese and Makassarese peoples, the dominant ethnic groups of South Sulawesi. In contrast to the extensive kingdoms established by these neighboring Buginese and Makassarese, the Toraja never united into a centralized political unit. Traditionally, Torajans lived in scattered mountaintop households, maintaining social ties through an elaborate system of ritual exchanges (Nooy-Palm 1979, 1986). It was not until the arrival of Dutch colonial forces in 1906 that the Toraja were formally brought together under a single political authority.

A few years after the Dutch annexed the highlands, missionaries from the Dutch Reformed Church began proselytizing among the Toraja. ${ }^{4}$ Although conversion was initially slow, it gathered momentum in the 1950s and 1960s. Scholars attribute the large number of conversions during this period to two primary factors: inroads made by mission schools, and the newly independent Indonesian government's policy of actively encouraging practitioners of indigenous religions to convert to world religions (Bigalke 1981). Today, over 80 per cent of the Sa'dan Toraja are Christians. (By contrast, over 85 per cent of Indonesia's population describe themselves as Muslims.) Only about 11 per cent of the Toraja people continue to practice the traditional Ways of the Ancestors (Aluk to Dolo), which entail the veneration of spirits, gods, and ancestors. Despite the fact that contemporary Torajans are predominantly Christian, they continue to sponsor and partake in elaborate funeral rituals that include pig and water buffalo sacrifices.

Toraja society is hierarchically organized on the bases of descent, wealth, age, and occupation. In precolonial times Torajan society was roughly divided into three social strata: the aristocracy, commoners, and slaves. Status was determined by birth, although economic aptitude or failure permitted some degree of social mobility. Today slavery is outlawed in Indonesia and rank is a delicate topic among Torajans. Not surprisingly, customs pertaining to showcasing rank are a particular focus of many Torajans' reformulation of cultural practices in the context of tourism development, as will be seen in the case immediately following this section.

Tourism to the Toraja highlands is a relatively recent development. Throughout the 1950s and early 1960s, poor roads and Muslim rebellions made it a challenge to travel in South Sulawesi. In the late 1960s, however, President Suharto began to encourage the development of the Indonesian tourism industry. Initially, government 
officials concentrated on developing and expanding tourism in Bali, Java, and Sumatra. In 1974, however, Indonesia issued its second Five Year Plan, which stressed the promotion of Outer Island destinations, including Tana Toraja (Crystal 1977; Spillane 1987). The touristic marketing of Tana Toraja was a phenomenal success: whereas in 1973 only 422 foreigners voyaged to the Toraja highlands, by 1994 over 53,000 foreign tourists and 205,000 domestic tourists were visiting the region annually.

Both the growing tourist and anthropological literature have helped make Torajans international celebrities, their culture an entity to be studied, dissected, photographed, and packaged for export (Adams 1988, 1990; Volkman 1990). Today's Torajans are increasingly exposed to outsider images of their culture. Local shops offer T-shirts and postcards depicting Torajan burial cliffs, "traditional Toraja villages," and "warrior dancers." Travel agency placards announcing local "funeral parties" and "celebrations of death" line the main street of Rantepao (one of the two major towns in Tana Toraja Regency). Tourism Board posters emblazoned with smiling female dancers beckoning, "Come to Tana Toraja: Land of the Heavenly Kings" decorate local cafes and living rooms. And Torajan villagers devotedly watch Indonesian television variety shows which routinely feature traditionally dressed Torajan singers seated on ornately carved Toraja rice barns. In short, contemporary Torajans are not only ethnically self-conscious, but are also avid consumers, manipulators, and critics of the ethnographic and touristic images of their culture.

Hand in hand with Torajans' emerging ethnic self-consciousness comes an objectification of culture, a tendency that is reinforced by the vocabulary of Indonesian cultural policy. Torajans are extremely fond of commenting to tourists and anthropologists alike that "we Torajans have more culture here." The implicit comparison is with their lowland rivals, the Buginese. Culture, then, becomes a measurable, quantifiable entity, reminiscent of Greenwood's (1977) observations. This objectification of culture has also brought new Torajan concerns about and obsessions with cultural authenticity, as will be discussed below.

Torajan touristic fame not only engenders ethnic self-consciousness, but it also brings a variety of other costs and benefits. On the one hand, it represents a new source of revenue, as well as the opportunity to gain favorable attention and grants from the government. On the other hand, tourism has a tendency to enhance the stereotype of the Toraja as a primitive and backwards people. Many Torajans have voiced the troubling tension they experience between being a celebrated tourist attraction and being portrayed as "primitive" with "joyful funeral festivals." Such tensions have prompted Torajan attempts to reinterpret their customs and reshape outsiders' images of their identity, as the cases discussed below illustrate.

\section{TAMING TRADITIONS: NE’ KE'TE'S FUNERAL RITUAL}

In January of 1987, I returned to Tana Toraja for the funeral of an aristocratic Torajan who had "adopted" me during my initial fieldwork. Ne' Ke'te' had been a 
prominent local figure, extremely active in civil and religious politics. His funeral promised to be an important event for the entire Torajan community. Traditionally, the Torajan funeral not only provides an opportunity to pay respect and debts to the family of the deceased, but also serves as an important arena for demonstrating one's social status (Crystal 1974, 1976; Nooy-Palm 1979; Koubi 1982; Volkman 1985). The more guests a funeral attracts, and the more water buffalo sacrificed, the more prestige the sponsors attain. ${ }^{5} \mathrm{Ne}$ ' Ke'te's funeral had thus been widely publicized. Thirty-thousand guests including three cabinet ministers, two governors, a foreign ambassador, and van loads of tourists were to attend. My Torajan family was faced with an issue that has confronted Torajans ever since tourism development began in the early 1970s: how to stage a large-scale ritual that would be deemed a success by several very different audiences; by locals, by Java-based government representatives, and by foreign tourists. ${ }^{6}$

Because of the size of the ritual and the amount of attention it was drawing from high-status outsiders, the funeral planning was extensive. The village's architectural transformation for the funeral began months in advance: kinsmen of the deceased built sprawling bamboo complexes around the central ritual arena. These colorfully painted pavilions were to shelter relations and funeral guests over the course of the ten-day ritual. ${ }^{7}$ One particularly grand and well-situated pavilion was erected for V.I.P. government visitors (“tamu V.I.P.”). A travel agency paid for the construction of its own pavilion where tourists would be able to rest and reload their cameras away from the bustle of the crowds.

The immense scale of the ritual required complex planning. Emulating government and church organization, a funeral secretary was chosen and some two dozen funeral committees were formed; including an entertainment committee, a clean water committee, a safety committee, and a documentation committee. Evenings in the months and weeks before the funeral ritual began were filled with committee meetings. Individuals who in smaller rituals had labored in a multitude of areas came to view their role in this event in terms of the committees to which they were assigned.

I was also drawn into this frenzy of funeral-committee activity. On the evening I arrived in the village, my Torajan family gave me a mimeographed list of funeral task forces and declared that I was assigned to two committees that would put my anthropological training to work: the "Funeral Documentation Committee" and the "V.I.P. Guest Reception Committee." At first I was deeply moved that they had devised a way in which I could participate as a "family member" in the funeral. Only later did I fully comprehend the political dimensions of my assignments. Recognizing the funeral ritual's potential to reinforce outsiders' images of Torajans as primitives, the family had devised a strategy to combat these negative stereotypes. The day before the V.I.P. guests arrived, they instructed me to greet them in traditional Torajan garb at the V.I.P. guest pavilion. They speculated that these guests would initially be amused at the "tourist gone overboard," then become awed (kagum) upon learning that I was the deceased's "adoptive daughter and family anthropologist" 
assigned to explain the funeral ritual to them. The family was explicit about what I was to tell the visiting dignitaries; I was to emphasize that they were not pagans but Christians, and point out the church hymns and ministers officiating at the ritual. As one Torajan kinsman observed, this time no visitors would return home thinking all Torajans were animists.

Moreover, the family was well aware of outsiders' perceptions of their funerary water buffalo sacrifices as wasteful and backwards. Over the years, a number of articles had appeared in the national newspaper, Kompas, criticizing Torajans for spending thousands of dollars on funeral ritual slaughters. Disturbed by government officials' and tourists' denigration of their sacrifices, the family stressed that I must not forget to tell the V.I.P. guests that the water buffalo meat would be redistributed, eventually reaching poorer villagers who often do without meat. "They won't believe us if we say it, but they'll believe you," they urged. "You're an anthropologist: you can convince them that our rituals are not wasteful." Finally, they quizzed me on aspects of the ritual itself, wanting to hear how I would explain the various rites to the V.I.P. guests. At one point I was asked what I would say about the palanquin leading the funeral procession. I answered with what I had been told during my fieldwork; that this covered litter held a descendant of a slave. This "slave litter" has traditionally cleared the path for the ensuing funeral party. Hearing this, the family members exchanged glances and quickly concluded that, although essentially correct, this answer would not meet with the approval of the government guests. One commented that a reference to slave descent would prompt disapproval from the government guests, and an elder suggested that perhaps it would be better to call this individual a helper (pembantu). After some discussion, this was deemed a suitable explanation.

At the start of the ten-day funeral ritual, family members, distant kin, friends, and other guests began to arrive with gifts of water buffalo, pigs, chickens, sugar, and other offerings. The temporary pavilions were filled with guests and the usually tranquil village was transformed into a bustling bamboo city. The ritual activities of the first three days were punctuated with frequent prayer sessions, water buffalo fights, and, in the evenings, ma'badong dances for the deceased. The majority of the visiting dignitaries were scheduled to visit on the fourth and sixth days, which were devoted to the rites termed ma'pasa' tedong (parading the water buffalo) and ma'palao (moving buffalo and deceased to the ritual field), respectively. Below is an excerpt from my journal recorded on the fourth day of the ritual.

In front of the tongkonans [ancestral houses] the buffalo herders were busy decorating their buffaloes with red and yellow cloth, gold cutouts, woven bits of grass and slices of squash. . . TVRI arrived on the scene equipped with gigantic video cameras and other recording instruments. A few foreign tourists began to show up, along with fleets of Indonesian tourists. Kakak and others sitting in the Secretariat Booth repeatedly made loudspeaker announcements in Indonesian and fractured English that tourists were not to sit on the rice barns, which were reserved for local leaders and their families.

. The decorated water buffaloes were then paraded, along with banners of $m a a^{\prime}$ [sacred textiles] and a large gong. Following this procession were the tau-tau [effigy of the deceased], the bereaved family members, etc. I briefly joined the family member section of the procession alongside Sarlota, then 
circled back to take some pictures, slipping between my roles of participant and observer. . . In the early afternoon family members sent me to talk to some of the visiting officials in the V.I.P. grandstand. This group included officials from the Jakarta and Ujung Pandang branches of the - - Bank. Sure enough, they asked how many pricey buffaloes were to be "wasted" as sacrifices at this "animist" ritual.

The following days brought similar questions from other V.I.P. guests. The family had correctly anticipated the responses their funeral would evoke and the narrative we had rehearsed (that they were Christians, that the buffalo meat would feed many distant villagers, and the euphemistic referral to "helpers" rather than "descendants of slaves") represented an attempt to divest the ritual of all aspects that were expected to prompt the disapproval of outsiders. In short, I was cleverly employed to dispel what they perceived to be negative stereotypes about their culture. Recognizing the power of outsider images over their own claims, they resorted to borrowing the authoritative voice of an outsider to challenge these images. As the Torajans drew on the authority of my discipline, degree, and race to establish the merit of their cultural practices, I became a party to the taming of Torajan traditions.

It is important to underscore that this conscious effort to sanitize Torajan ethnic imagery for an outsider audience did not divest the ritual of its salience. In the eyes of the Torajans, today as in the past, the ritual remained an arena for status enhancement; in this instance, however, it was not only for the deceased's lineage, but for the entire ethnic group. Ironically, the presence of these visiting dignitaries at the funeral both bolstered and weakened the prestige of the family. In deference to the dignitaries, not only were funeral speeches condensed and dances explained, but various rites were juggled, or delayed. For instance, on the seventh day of the ritual (ma'palao), the V.I.P. guests were an hour late. In the traditional past, on that day just after noon the corpse would be transported in an elaborate procession to an ornately carved tower (lakkian) situated at the edge of the ritual field. This time several hundred participants waited in the scorching sun until the tardy dignitaries finally arrived in the afternoon and the signal to begin the procession was given. On the sidelines, local guests grumbled that things were not being done in accordance with traditions, that the ritual was not "authentic." Thus, while the very presence of these important officials from far-off places conferred prestige on the family, it also fueled rivals' criticism of their ritual as unauthentic.

As with colonialism, this case shows how tourism development provides a fertile context in which custom is reinterpreted and reframed. Tourism and the attendant attention from the national Indonesian government are prompting new challenges to local forms of meaning, power, prestige, and identity. Examining this carefully staged funeral ritual at close range lends deeper insights into the microprocesses involved in the renegotiation of tradition and the reformulation of ethnic imagery. This case also offers insight into the question raised earlier, namely, how Torajan rituals maintain their salience in the context of touristic promotion and Torajan cultural self-consciousness. Although Torajan rituals are increasingly self-conscious productions, their meaning is clearly not being lost: rather, old themes are being 
played on a new stage. Touristic celebrity provides the Toraja with new audiences for augmenting their status and a new basis ("authenticity") on which to criticize the rituals of their rivals. In other words, large-scale rituals are now aimed not only at enhancing local status but at increasing Torajan prestige on a national and international level. In this process, aspects of Torajan tradition that outsiders might disdain (e.g., costly water buffalo sacrifices, the heritage of slavery) are either played down or justified in anthropological terms. In this way, controversial traditions are tamed and the image of Torajan ethnic identity is enhanced.

\section{THE LOCAL GUIDE TRAINING WORKSHOP}

A second event further illustrates the microprocesses whereby Torajans are actively engaged in renegotiating their history out of concern for their touristic image. In 1985, the South Sulawesi provincial tourism officials determined that the unlicensed "wild guides" (guide liar) flourishing in Tana Toraja were a potential liability. These wild guides are for the most part young unemployed or underemployed Torajan men who seek their clients at the restaurants and hotels favored by independent tourists. Although a few of these young men are reputed to be hustlers or rascals prone to overindulging in palm wine, for the most part they are entrepreneurs who have taught themselves one or two European languages and enjoy associating with foreigners. The 1985 decree that only officially licensed guides would be allowed to escort tourists in Tana Toraja was a serious blow to them. As guide-training courses were both costly and distant (eight hours away in the Buginese-Makassarese city of Ujung Pandang), these Torajans recognized that their income from guiding in their own homeland was threatened. In the eyes of many Torajans, this new certification requirement would hasten the encroaching monopoly of Buginese guides in Tana Toraja. As several guides lamented, not only was their livelihood at stake, but now nonlocal guides who knew little about Torajan culture would be controlling what was said about Torajans to tourists. Recognizing these issues, government officials in Tana Toraja Regency organized a Local Guide Training Workshop (Kursus Pramuwisata Khusus Tator), designed as a crash course in guiding skills and presentations.

In November of 1985, 88 aspiring Torajan guides and representatives from Toraja's most frequented tourist destinations attended the first such workshop. One of the many goals of the two-week-long workshop was to develop a uniform Torajan history and mythology to be presented to tourists, thus combatting the perceived misrepresentations of Tana Toraja articulated by nonlocal guides. Moreover, for the workshop leaders, the wide regional diversity of Torajan origin myths was troubling; they feared tourists would hear conflicting stories and come to question Torajans' credibility. In essence, the workshop involved an active attempt to achieve consensus on the image of Torajans presented to outsiders. Ironically, what was intended to be a unified move against outside dominance provoked local dissent. The biggest issues debated at the workshop centered on whose version of Torajan history would become 
"official." Traditionally, each group of Torajan nobles bases its claims to high rank on descent from various heavenly ancestors who descended onto local mountaintops centuries ago. For the nobles present, it was important that their particular celestial forebears be incorporated into the official version of Torajan history told to tourists. Formal recognition of a particular family's mythic history and landmarks meant continued substantiation of their high rank within Torajan society. Moreover, official recognition had the potential to attract to one's village rich, presumably generous, foreign tourists as well as an assortment of concrete touristic amenities, such as paved roads, outhouses, and telephone booths. Given these considerations, the selection of speakers for the workshop became a politically charged issue with not only symbolic but economic ramifications.

Ultimately, several prominent aristocrats in the community who had celebrated reputations as cultural experts, strong political ties, and genealogical links to already established tourist villages were chosen to make presentations at the workshop. Their lecture topics included Torajan history, cosmology, traditional dress, and architecture. The aspiring local guides were then tested on this material and eventually awarded with official certificates. Thus, the aristocratic speakers' particular versions of the Torajan past became the standard text for presentation to outsiders. Not everyone was happy with the situation. Aspiring guides from villages whose myths were not taught grumbled that a false version of Torajan history was being foisted upon them. One articulate young guide stood up on the final day of the workshop and pointedly asked the moderator, "After two weeks of training meetings, I am left with the question, just what is Toraja? Is it only Ke'te' village or the Sangalla region where our speakers come from? Or is it also the other villages over the hill, where many of us here come from? Can we really standardize Torajan history? Won't something be lost?" Not surprisingly, the moderator skirted the question. Although most of the "wild guides" passed the Training Workshop exam and are now certified local guides, the attempt to create a uniform Torajan history at this workshop was not successful. It is noteworthy, however, that these efforts were motivated by Torajans' concerns with the opinions of outsiders (e.g., their fears that the existence of contradictory versions of Torajan mythic history would prompt tourists to judge Torajans negatively, as "storytelling liars"). Moreover, as evidenced in this case, the attempts of Torajan aristocratic leaders to enhance their culture's image vis-à-vis outsiders prompted some unexpected, disturbing questions about the local distribution of power.

\section{DISCUSSION}

The funeral and the Guide Training Workshop reveal some of the political and symbolic issues inherent in the renegotiation of Torajan ritual and history. Suddenly finding themselves in the international spotlight, the Torajans are re-examining their rituals and consciously reshaping their traditions and past. Careful attention to the Toraja case reveals some of the microprocesses involved in the touristic invention of 
tradition. As we have seen, much of contemporary Torajan sculpting of their customs and history grows out of concerns regarding status, power, and authority. Tourism, like colonialism, creates a fertile context for the reformulation of history and custom, as it ushers in new challenges to local forms of meaning, power, and identity. The Toraja case also emphasized that such self-conscious remodeling of ritual and history hardly comes hand in hand with a divestment in the meaning and emotive power of culture. All too often, discussions in the ethnic tourism literature of staged authenticity leave the reader to mistakenly assume that these processes are invariably tantamount to a collapse in the significance of these ritual performances to local peoples. Though a number of Torajans today are rearranging and condensing aspects of their rituals to accommodate visiting dignitaries, their funerals continue to be vibrant arenas for honoring the dead as well as for establishing a family's local authority. The Toraja case thus lends further support to recent critiques of the concept of staged authenticity as an intrinsic aspect of tourism (Crick 1989; Urry 1990; Adams 1996). Whereas other critiques have focused on underscoring the important point that all cultures engage in presumably unauthentic staging, so even staged behaviors entail authenticity, this article makes a companion argument: that self-conscious cultural (re)formulation does not necessarily imply a collapse in meaning or emotive power. In this sense, this article lends support to the growing sentiment that it is time to rethink the discourse of "authenticity" and "staged authenticity."

Moreover, these cases from Tana Toraja offer lessons for ethnic tourism researchers who have typically tended to assume that touristic promotion brings a loss of agency to indigenous peoples (e.g., Greenwood 1977; Erisman 1983; Urbanowicz 1989; van den Berghe 1980, 1994). As this article has illustrated, tourism development does not always entail a complete loss of agency for local people. While Torajans have little control over tourism policy-making and the flow of tourism revenues, they are hardly passive when faced with some of the troubling dimensions of this form of development. Indeed, they are not resigned to accepting representations depicting them as pagan primitives given to inappropriately extravagant funeral rituals, but are actively engaged in ingenious political strategies to adjust and enhance their group's image and vigorously challenge and contest the perceived threats to their identity and power.

\section{NOTES}

1. This paper is based on research supported by a Fulbright Fellowship and Gowen research funds administered by the University of Washington. Versions of this article were originally presented at the 1987 American Anthropological Association Annual Meeting and at the 1991 Conference on Southeast Asian Studies at the University of California, Berkeley. I thank Carter Bentley, Eric Crystal, Christina Fink, Jill Forshee, Miriam Kahn, Charles F. Keyes, Greg LeRoy, Simon Ottenberg, and Richard Scaglion for their thoughtful comments.

2. Pseudonyms are used throughout this paper. 
3. Government tourism officials calculated this figure by comparing the number of tourist ticket sales at the most popular tourist sites with occupancy rates and guest logs at local hotels, inns, and home stays (Rombelayuk, pers. comm.).

4. See Bigalke (1981) for the historical role of the Dutch Reformed Church in fortifying Torajan ethnic consciousness.

5. Given this traditional orientation, the presence of Indonesian government officials, tourists, and other outsiders at Toraja funerals is generally accepted as further evidence of the deceased's drawing power and the success of the ritual. Outsiders, like other funeral guests, are expected to bring gifts (cigarettes, sugar, etc.) to the funeral sponsors. While Torajans acknowledged that tourists who did not bring offerings yet consumed funeral meals could become economically burdensome to their hosts, they tended to be critical of those atypical and few families who charged admission to their funerals. These families, they declared, were going against age-old Torajan values of generosity: to charge admission to funerals was not only an affront to tradition but threatened to give the Toraja a reputation for being greedy. These statements convey their concerns for authenticity and their ethnic image.

6. It is noteworthy that they were least concerned with the opinions of tourists-the opinions of locals and government officials were what really mattered.

7. Save for close relatives of the deceased, most Torajans attend for just a few days, sometimes coming and going between their own homes. Most package tourists generally visit funerals for only a few hours as a part of the day's tour and are bussed back to their hotels in town to eat and sleep.

\section{BIBLIOGRAPHY}

Adams, K. M. 1984. "Come to Tana Toraja, Land of the Heavenly Kings": Travel Agents as Brokers in Ethnicity. Annals of Tourism Research 11(3):469-85.

1988. Carving a New Identity: Ethnic and Artistic Change in Tana Toraja, Indonesia. Ph.D. dissertation, University of Washington. Seattle.

1990. Cultural Commoditization in Tana Toraja, Indonesia. Cultural Survival Quarterly 14(1):31-34

1993a. Club Dead, Not Club Med: Staging Death in Contemporary Tana Toraja (Indonesia). Southeast Asian Journal of Social Science 21(2):62-72.

1993b. Theologians, Tourists and Thieves: The Torajan Effigy of the Dead in Modernizing Indonesia. The Kyoto Journal 22:38-45.

1995. Making Up the Toraja? The Appropriation of Tourism, Anthropology, and Museums for Politics in Upland Sulawesi, Indonesia. Ethnology 34(2):143-53.

Adams, V. 1996. Tigers of the Snow and Other Virtual Sherpas: An Ethnography of Himalayan Encounters. Princeton.

Bigalke, T. 1981. A Social History of "Tana Toraja” 1870-1965. Ph.D. Dissertation, University of Wisconsin. Madison.

Clifford, J. 1988. The Predicament of Culture: Twentieth-Century Ethnography, Literature, and Art. Cambridge.

Cohen, E. 1988. Authenticity and Commoditization in Tourism. Annals of Tourism Research 15(3):37186.

1989. "Primitive and Remote": Hill Tribe Trekking in Thailand. Annals of Tourism Research 16(1):30-61.

Crick, M. 1989. Representations of International Tourism in the Social Sciences: Sun, Sex, Sights, Savings, and Servility. Annual Review of Anthropology 18:307-44.

Crystal, E. 1974. Cooking Pot Politics. Indonesia 18:118-51.

1976. Ceremonies of the Ancestors. Pacific Discovery 29(1):9-19.

1977. Tourism in Toraja (Sulawesi, Indonesia). Hosts and Guests: The Anthropology of Tourism, ed. V. Smith, pp. 139-68. Philadelphia. 
1994. Rape of the Ancestors: Discovery, Display and Destruction of the Ancestral Statuary of Tana Toraja. Fragile Traditions: Indonesian Art in Jeopardy, ed. P. M. Taylor, pp. 29-41. Honolulu.

Erisman, M. 1983. Tourism and Cultural Dependency in the West Indies. Annals of Tourism Research 10:337-62.

Greenwood, D. 1977. Culture by the Pound: An Anthropological Perspective on Tourism as Cultural Commoditization. Hosts and Guests: The Anthropology of Tourism, ed. V. Smith, pp. 129-38. Philadelphia.

Handler, R., and J. Linnekin. 1984. Tradition, Genuine or Spurious. Journal of American Folklore 97:273-90.

Hanson, A. 1989. The Making of The Maori: Cultural Invention and Its Logic. American Anthropologist 91:890-902.

Hobsbawm, E. J., and T. Ranger (eds.). 1983. The Invention of Tradition. Cambridge.

Jackson, J. 1989. Is There a Way to Talk about Making Culture Without Making Enemies? Dialectical Anthropology 14:127-43.

Keesing, R. 1989. Creating the Past: Custom and Identity in the Pacific. The Contemporary Pacific 1/2:19-42.

Keesing, R., and R. Tonkinson (eds.). 1982. Reinventing Traditional Culture: The Politics of Custom in Island Melanesia. Mankind 13:279-399.

Koubi, J. 1982. Rambu Solo": "La Fumée descend": Le Culte des morts chez les Toradja du sud. Paris.

Linnekin, J. 1983. Defining Tradition: Variations on the Hawaiian Identity. American Ethnologist 10:241-52.

1992. On the Theory and Politics of Cultural Construction in the Pacific. Oceania 62:249-63.

MacCannell, D. 1973. Staged Authenticity: Arrangements of Social Space in Tourist Settings. American Journal of Sociology 79(3):589-603.

1976. The Tourist: A New Theory of the Leisure Class. London.

1992. Empty Meeting Ground: The Tourist Papers. London.

Nooy-Palm, H. 1979. The Sa'dan Toraja: A Study of Their Social Life and Religion. Vol. 1: Organization, Symbols and Beliefs. The Hague.

1986. The Sa'dan Toraja: A Study of their Social Life and Religion. Vol 2.: Rituals of the East and West. Dordrecht.

Spillane, J. J. 1987. Pariwisata Indonesia: Seiarah dan Prospeknya. Yogyakarta.

Urbanowicz, C. F. 1989. Tourism in Tonga Revisited: Continued Troubled Times? Hosts and Guests: The Anthropology of Tourism, ed. V. Smith, pp. 105-18. Philadelphia.

Urry, J. 1990. The Tourist Gaze: Leisure and Travel in Contemporary Societies. London.

van den Berghe, P. 1980. Tourism as Ethnic Relations. Ethnic and Racial Studies 3:375-92. 1994. The Quest for the Other: Ethnic Tourism in San Cristobal, Mexico. Seattle.

Volkman, T. 1985. Feasts of Honor: Ritual and Change in the Toraja Highlands. Urbana. 1987. Mortuary Tourism in Tana Toraja. Indonesian Religions in Transition, eds. R. S. Kipp and S. Rodgers, p. 161-67. Tucson.

1990. Visions and Revisions: Toraja Culture and the Tourist Gaze. American Ethnologist 17(1):91-110.

Wagner, R. 1981 (1975). The Invention of Culture. Englewood Cliffs.

White, G. 1991. Identity through History: Living Stories in a Solomon Islands Society. Cambridge.

White, G., and L. Lindstrom (eds.). 1993. Custom Today in Oceania. Anthropological Forum No. 6 (Special Issue).

Yamashita, S. 1994. Manipulating Ethnic Tradition: The Funeral Ceremony, Tourism and Television among the Toraja of Sulawesi. Indonesia 58:69-82. 